\title{
Do Management Jobs Make Women Happier as Well? Empirical Evidence for Switzerland
}

\author{
Yvonne Seiler Zimmermann ${ }^{1}$, Gabrielle Wanzenried ${ }^{2 *}$ \\ ${ }^{1}$ IFZ Institute of Financial Services Zug, Lucerne University of Applied Sciences and Arts, Campus \\ Zug-Rotkreuz, Suurstoffi 1, CH-6343 Rotkreuz, Switzerland
}

${ }^{2}$ School of Management and Engineering Vaud, University of Applied Sciences of Western Switzerland

\section{Keywords:}

Management Jobs; Job and Life Satisfaction; Gender Differences; Ordered logit model

\section{Received}

23 August 2019

Received in revised form

22 October 2019

Accepted

22 October 2019

\begin{abstract}
Management jobs are typically associated with a higher level of responsibility, more interesting work, a higher pay check and more social prestige, but also to a larger commitment, longer work hours and less time for family and leisure as well as more stress compared to non-management jobs. This study investigates the impacts of a management position on satisfaction with life in general, often causally called happiness, job satisfaction as well as satisfaction with the financial situation. In particular, the paper also explores potential differences between men and women in this respect. We use data from the Swiss Houshehold Panel (SHP) up to the year 2017 and estimate ordinal generalized linear models (OGLM) in order to explain the different satisfaction variables by work-related, person-specific, and integration-specific factors. Also, we suggest a new approach to control for reverse causality. In contrast to other studies, we find that management positions do not only increase the overall subjective well-being for men, but also for women. Interferences between work and private life decrease the subjective well-being overall, but men in management positions additionally witness negative effects from these interferences, while women in management position seem to be more stress-resistant. Our findings reveal some fundamental differences between men and women with respect to person- and jobrelated factors affecting satisfaction with life in general as well as with the professional situation. Also, the results point to the existing and still largely unexploited potential of having women in management positions.
\end{abstract}

Correspondence: 


\section{Introduction}

Management positions are generally jobs with an above average amount of responsibilities, interesting work duties with decision power, financial benefits and social prestige. At the same time, such positions are expected to require long working hours, a high personal involvement and possibly also stress, and there is less time left to spend with families, friends and for leisure activities. Accordingly, the outcome of holding such a position on an individual's well-being is a priori unclear, given that there are positive as well as negative factors which are all expected to affect a person's happiness.

Even though the determinants of individuals' well-being are quite well researched (e.g., Easterlin, 2001; Frey \& Stutzer, 2002.). The particular question of the impacts of holding a management position on a person's well-being has been hardly investigated. The purpose of our paper is to focus on this question and to see whether there exist differences between men and women with this respect. Accordingly, the key questions of our research are as follows: What is the impact of holding a management position on a person's individual well-being, after having controlled for other possible aspects as documented in the literature and which might potentially influence the personal happiness as well, such as, age, education, family situation, income, living situation and social contacts? What differences do exist between men and women with respect to the different dimensions of subjective well-being and its determinants? Besides considering the satisfaction with life in general, which is our main happiness measure, we also look at the satisfaction with the job and the satisfaction with the financial situation. Note that we use individual well-being as a substitute for life satisfaction, and also casually call it happiness, given that life satisfaction is the most commonly used concept in today's happiness research (Veenhoven 2013).

The investigation of these issues is important from several points of view. First, being happy is the goal of most if not all individuals (e.g., Diener, Suh, Smith, \& Shao, 1995; Diener, 2000; Veenhoven, 2010). Given that the average person among the working population spends a significant part of his or her time at work, the professional environment and the respective working conditions are expected to affect a person's happiness significantly. Second, the individual well-being is also important from a societal and economic point of view, given that it also affects a country's performance on an aggregate level and finally its welfare (Lyubomirsky, King, \& Diener, 2005). Third, the upcoming demographic changes will lead to a shortage of persons in the workforce in general and managers in particular. Increasing the job participation rate of women on different hierarchical levels and in higher level jobs in particular is one way to at least partly compensate this shortage. Such a development would also stand in line with planned revision of the Swiss corporation law, which foresee target values of women on boards and in management positions of publicly listed companies. ${ }^{1}$ In order to motivate women for such high profile positions, it is important and necessary to know about their preferences with respect to the work environment, and such knowledge also allows to adjust the institutional and organizational framework accordingly. Finally, gender research has so far hardly addressed these particular questions, and there do not exist any results for Switzerland as well.

The literature on the determinants of life satisfaction is growing steadily, and there exist also several studies for Switzerland. In particular, different aspects such as the influence of marriage, having children, volunteering, commuting or watching TV on a person's happiness have been investigated (e.g., Frey \& Stutzer, 2005, 2010). To our best knowledge, however, no study exists for Switzerland which analyzes the life satisfaction of managers in comparison to non-managers, and whether there exist differences between men and women in this respect.

1 See also the newsletter of the Schweizerischen Arbeitgeberverbandes from Dec. 2016. 
In contrast, we know of at least two closely related studies based on German data which are focusing on the well-being of individuals in management positions. Our reference study by Trzcinski and Holst (2012) is based on the German Socio-economic Panel for the years 1984 to 2006 and examines to what extent gender differences in self-reported subjective well-being is associated with occupying a highlevel managerial position in the labor market. The authors simultaneously examine the relationship between subjective life satisfaction and four different categories of work status, while controlling at the same time for a wide range of personality, attitude and value, and demographic factors. Their results indicate, among other factors, that there exists a clear hierarchy for men in terms of how their status within the labor market affects their subjective well-being, while no such effect was found for women. In particular, men in leadership positions reported the highest level of subjective life satisfaction, while women in leadership positions did not significantly differ from women without leadership position with respect to their subjective life satisfaction. The authors conclude that "men can have it all", while women must still choose between career and family. Given that the data goes back to more than ten years and many organizations implemented programs in order to facilitate the combination of career and family, the question arises whether this finding is still valid today. Accordingly, it would be interesting to repeat the analyses with the newest available data.

A more recent study by Brockman, Koch, Diederich and Edling (2017) uses data from the German panel dataset (GSOEP) over the years from 1984 to 2011. The authors mention that biological constraints and substitutive mechanisms determine the subjective well-being of female managers. They find that women's terminated fertility has a negative impact on women's life satisfaction between the ages of 35 and 45, which is also the time period when managerial careers usually take off. While money and spare time are able to compensate for this biological difference, women need to be compensated by much more income in comparison to men in order to give up spare time for work. Accordingly, they conclude that "....in order to reach better gender equality in leadership positions, women must be either paid higher incomes (on average around 10\%) or must be incentivized with more spare time than men." As the authors also mention an interesting consequence, which is at the same time a policy recommendation for corporations, new incentive systems would be required in order to convince more women to take over leadership positions.

There also exist studies on the differences between men and women with respect to the interactions between life satisfaction and working conditions in general, without focusing on management positions in general. According to Treas, van der Lippe, and Tsui-o (2011), for instance, the role of paid work for women's life satisfaction is quite controversially discussed, and many factors have to be taken into account, and it also depends on how life satisfaction is measured. Treas et al. (2011) use data from 28 countries for the year 2002 and provide empirical evidence for housewives being more satisfied than women who work full-time outside their home, but they are not happier than women who work parttime out of their home. As they outline, the results also depend on other factors such as the household income, whether the partner is doing household work, whether there are conflicts with the partner and stress in general.

We use data from the Swiss Household Panel SHP. Our main results refer to the data for the year 2017, which include a total of 4'295 observations, 2'096 for men and 2'199 for women. Given our descriptive statistics, we do not find any differences between men and women with respect to our life satisfaction and financial satisfaction, but women report significantly higher job satisfaction in comparison to men, even though the absolute difference is not very large. In contrast, we find a higher satisfaction with the financial situation of men compared to women in case we consider managers only. 
Our main results from the regression analyses, which analyze the determinants of individual well-being or satisfaction, provide evidence for the fact that holding a management position has a strong and positive effect on the life satisfaction of men, but a weaker but still a positive and significant effect on the life satisfaction of women. This result stands in contrast to former studies by Trzcinski and Holst (2012) and Brockman et al. (2017). Existing interferences between the work and private life negatively affect the well-being of both men and women, the latter to an even stronger extent. To see the impact of holding a management position on this negative impact, we include an interaction term in our model. From our results we conclude that men in management positions witness an additional negative impact on their subjective well-being, while women managers do not additionally suffer from those interferences between work and private life in comparison to women without management positions. For the job satisfaction and financial satisfaction, the interaction term is positive and significant for women, meaning that women in management positions seem to be able to at least partly compensate the negative impact from interferences between work and private life on their subjective well-being by holding a management position. These results are interesting because they suggest that female managers seem to be immune to additional stress caused by the interferences between work and private life. These findings point to the non-trivial but in Switzerland largely unexploited potential of women in management positions, which should be added to the discussion about the underrepresentation of women in high-level professional positions. Note that we control for a large set of person-specific workspecific as well as integration-specific factors which all are expected to impact subjective well-being. Given that our results might suffer from a potential causality problem, i.e. holding a management position might not only affect a person's subjective well-being, but the subjective well-being might also influence whether a person is holding a management position or not, we carry out additional analyzes and are able to show that the underlying model assumption of the causality from holding a management position on the subjective well-being is valid.

The new aspects of our paper are as follows. It is the first empirical study that investigates the impact of management positions on life-, job and financial satisfaction in Switzerland and whether there exist any differences between men and women. So far, the number of studies on this topic is very limited. Our reference study by Trzcinski and Holst (2012) as well as the newer study by Brockman et al. (2017) both use data from the German Socio-economic Panel (GSOEP) and, therefore, consider Germany only. Given that Switzerland has a highly developed economy, but at the same time still a rather low share of women in management positions in the international contex $\mathrm{t}^{2}$, it is even more important to investigate these issues for such a country. Second, we consider slightly different aspects of subjective well-being by including a broader set of satisfaction measures. Besides our main measure of life satisfaction, we additionally consider the job satisfaction and the satisfaction with the financial situation. This is also possible because we use another data set compared to the existing studies. Third, our main results are based on the year 2017, and additional analyses use data that goes back up to 2002. As mentioned above, over the last ten years, many corporations implemented measures to facilitate work and family life, and in particular also for management positions. Accordingly, it is important to use new data in order to capture possible new developments. Fourth, we use the appropriate estimation method to deal with data of subjective well-being. In contrast to existing studies, for example Bucchianeri (2011), we apply an improved estimation methodology which is suitable for this type of data. In concrete, we use ordinal generalized linear models (OGLM) for our estimations and eliminate the problem of

2 According to a recent study by Dawson et al, (2016), the share of women in senior management roles is $6.8 \%$ for Switzerland in 2015, while this share amounts to $12.8 \%$ for Europe. 
heterogeneity in the residuals and potentially biased estimates. Finally, we address the problem of a potential reverse causality problem which might exist in this type of analyses. In concrete terms, the underlying assumption which is commonly made also in other papers (e.g., Brockman et al., 2017; Bucchianeri, 2011; Trzcinski \& Holst, 2012) assumes that holding a management position has an impact on a person's life satisfaction or happiness. However, one might argue that the causality goes the other way around, i.e. happier people might be more likely to select jobs with management duties and/or being chosen for such positions. Such an issue would lead to a potential endogeneity problem and inconsistent estimates. We address this issue by looking at a restricted sample, though based on data from all available years over the time period from 2002 to 2017, and to consider only those persons who had a change in their job status, but not change with respect to other control variables except age, income and working hours. We then analyze the change in life satisfaction for those individuals only, and our results are able to justify the commonly made assumption of the job status having an impact on life satisfaction, and not the other way around.

Our results are interesting from an academic point of view, but they may also provide valuable inputs for the business world. In particular, our findings refer to potential benefits for organizations from hiring women for management positions. Not only are happy employees expected to be more productive, but especially also stress resistant managers provide a valuable asset for any company. Such an insight might be even more important in view of the still existing underrepresentation of women in management positions, which also holds for Switzerland. Despite the fact that many companies have implemented special programs to increase the number of women in management jobs, the share of female managers seems to have increased only slightly over the last decade and even to stagnate since a few years ${ }^{3}$. Even though our analyses include many, but not all possible factors which might explain satisfaction from work and leadership duties in particular, our results suggest that women fundamentally differ from men with respect to their preferences, and this has, among other aspects, also consequences for their job selection. To go one step further, these findings should be taken into account when selecting candidates for managerial positions. The paper is structured as follows: Section 2 outlines the empirical model and section 3 describes the data. The results can be found in section 4 , and section 5 concludes.

\section{Empirical Model and Estimation Method}

We use an ordered logit model to explain different aspects of satisfaction by a set of relevant workrelated, person-specific, and integration-specific factors which determine an individual's wellbeing. Measures of subjective well-being measures are typically ordinal variables, therefore, not so easy to interpret. However, they are increasingly accepted as a satisfactory empirical approximation to individual utility (Frey \& Stutzer, 2002).

Our dependent variable $y_{j}^{*}$ is an ordinal variable and refers to satisfaction with life in general. We use two additional satisfaction variables to consider additional aspects of satisfaction, namely the satisfaction with the job and the satisfaction with the financial satisfaction.

The independent variables consist of four sets of factors. The main variable of interest is whether the individual holds a management position or does not hold such a position, as captured by the dummy variable Manager $_{i}$. We then consider three sets of control variables, which are all expected to affect life satisfaction of individuals and which we include sequentially into the model. In model

3 According to the Swiss office of statistics, the share of women in management positions overall amounted to about $29 \%$ in 1996 , whereas this share was $36 \%$ in 2016 . See also

https://www.bfs.admin.ch/bfs/de/home/statistiken/kataloge-datenbanken/grafiken.assetdetail.2680648.html. 
(1), we include one work-related variable $W_{i}$, capturing whether a person is over- or underqualified for his or her job. In model (2), we additionally consider person-specific variables $P_{i k}$ such as age, of which we also include the square in order to take into account any nonlinear effects, the household income, the nationality by differentiating between Swiss and non-Swiss, the health status and the fact whether the person has an university education or not.

In model (3), we add integrated-specific aspects $I_{i l}$ which are expected to have an effect on a person's subjective well-being, according to the relevant literature. In concrete terms, we control for the fact whether a person is living in a partnership, whether there are children living in the same household, whether the person witnesses interferences between the work and the private life, and we also interact this interference variable with the dummy variable for being a manager.

Note that our variable selection contains similar determinants of subjective life satisfaction than Trzcinski and Holst (2012), except that our data set does not contain any information on the personality traits. In contrast, we include additional variables like the under- or over-qualification at work and the existence of interference between work and private life. A detailed description of the regression variables can be found in Table 1.

The econometric model is given by equations (1) to (3), i.e.,

$$
\begin{gathered}
\operatorname{Pr}\left(y_{i}^{*}\right)=\alpha_{0}+\alpha_{1} \text { Manager }_{i}+\alpha_{2 j} W_{i}+\varepsilon_{i} \\
\operatorname{Pr}\left(y_{i}^{*}\right)=\alpha_{0}+\alpha_{1} \text { Manager }_{i}+\alpha_{2 j} W_{i}+\alpha_{3 k} P_{i k}+\varepsilon_{i} \\
\operatorname{Pr}\left(y_{i}^{*}\right)=\alpha_{0}+\alpha_{1} \text { Manager }_{i}+\alpha_{2 j} W_{i}+\alpha_{3 k} P_{i k}+\alpha_{4 l} I_{i l}+\varepsilon_{i}
\end{gathered}
$$

We estimate our equations by ordinal generalized linear models. When a binary or ordinal regression model incorrectly assumes that error variances are the same for all cases, the standard errors are wrong and (unlike ordinary least squares regression) the parameter estimates are biased (Yatchew \& Griliches 1985). Such models explicitly specify the determinants of heteroscedasticity in an attempt to correct for it. Note that we estimate the models separately for men and women, in order to allow all the coefficients to be gender-specific. This approach stands in line with other authors, for example, Trzcinski and Holst (2012).

Given our main question and the corresponding model specification, our analyses may be affected by a potential reverse causality problem. In particular, holding a management position may not only have an impact on a person's happiness, but happier people might be more likely to select jobs with management duties. Such an issue would lead to a potential endogeneity problem and inconsistent estimates. Our solution to this potential problem, which has been addressed neither by Trzcinski and Holst (2012) nor by Brockman et al. (2017), is to consider a restricted sample of individuals who had a change in the job status with respect to holding a management position, but no change with respect to the control variables except age, income and working hours. For this restricted sample, for which we use all the available years in our data set, namely the years 2002 to 2015, we compare the change in subjective well-being depending on whether the persons moved in or out of a management position. The analysis can be found below and the results support our underlying assumption that holding a management position affects the level of subjective wellbeing, and that our results do not suffer from a potential reverse causality problem. 


\section{Data Description}

Our analysis is based on the Swiss Household Panel (SHP) data. According to its website, the principal aim of the SHP is to observe social change, in particular the dynamics of changing living conditions and representations in the populations of Switzerland (see also http://forscenter.ch/en/oursurveys/swiss-household-panel/). The SHP is run by FORS, the Swiss Centre of Expertise in Social Sciences. Data are collected annually using computer-assisted telephone interviewing (CATI). The SHP data are available free of charge for the scientific community.

Our sample includes a total of 4295 observations for the year 2017. According to standard procedure (e.g., Gazareth, Iglesias, Crettaz, \& Suter, 2018), we keep for each household the household head only, defined as the main earner. All the individual characteristics refer to the household head, while some determinants refer to the household. Note that whether the household head is female or male occurs about with the same probability in our sample. Analogous to, e.g., Brockman et al. (2017 and Trzcinski and Holst (2012), we consider women and men separately in order to take into account different preferences. Also, we exclude students, and all other persons following a full-time educational training from our sample as well as retired people. The definitions of our regression variables can be found in Table 1.

Table 1

Definition of Variables

\begin{tabular}{|c|c|}
\hline Variables & Description \\
\hline \multicolumn{2}{|l|}{ Dependent } \\
\hline Life satisfaction & $\begin{array}{l}\text { Satisfaction with life in general of individual } i \text {, ordinal variable with } 10 \text { possible values }\{0, \ldots, 10\}, \\
\text { where } 1=\text { not satisfied at all, } 10=\text { fully satisfied (SHP variable } p 17 c 44 \text { ) }\end{array}$ \\
\hline Job satisfaction & $\begin{array}{l}\text { Satisfaction with job in general of individual } i \text {; ordinal variable with } 10 \text { possible values }\{0, \ldots, 10\} \\
\text { where } 1=\text { not satisfied at all, } 10=\text { fully satisfied (SHP variable } p 17 w 228)\end{array}$ \\
\hline Financial satisfaction & $\begin{array}{l}\text { Satisfaction with financial situation of individual } i \text {, ordinal variable with } 10 \text { possible values }\{0, \ldots, 10\} \text {, } \\
\text { where } 1=\text { not satisfied at all, } 10=\text { fully satisfied (SHP variable } p 17 i 01)\end{array}$ \\
\hline \multicolumn{2}{|l|}{ Independent } \\
\hline \multirow[t]{2}{*}{ Manager } & Dummy: One if person holds a management position, and zero else (based on SHP variable p17w34) \\
\hline & Control variables I: Work related factors $\left(W_{i}\right)$ \\
\hline Misqualification & $\begin{array}{l}\text { Job qualification. Dummy variable: is one if qualifications for job are too high, too low or unrelated to } \\
\text { job, and zero else (based on SHP variable } p 17 w 100) \\
\text { Control variables II: Person-specific factors }\left(P_{i}\right)\end{array}$ \\
\hline Age & Age of person in years (SHP variable age 17) \\
\hline Swiss & Nationality. Dummy variable: is one if person is Swiss, and zero else (based on SHP variable $n a t \_1 \_17$ ) \\
\hline Good health & $\begin{array}{l}\text { Health status. Dummy variable: is one person has good self-reported health, and zero else (based on } \\
\text { SHP variable } p 17 c 01 \text { ) }\end{array}$ \\
\hline University education & $\begin{array}{l}\text { University education. Dummy variable: is one if person has an university degree as highest education, } \\
\text { and zero else (based on SHP variable educat17) }\end{array}$ \\
\hline \multirow[t]{2}{*}{ Household income } & Yearly net household income in CHF (SHP variable i17wyn) \\
\hline & Control variables III: Integration-specific factors $\left(I_{i}\right)$ \\
\hline Living with partner & $\begin{array}{l}\text { Cohabitation status. Dummy variable: is one if the person is living with a partner, zero else (based on } \\
\text { SHP variable hldtyp17) }\end{array}$ \\
\hline Children in household & $\begin{array}{l}\text { Offspring. Dummy variable: is one if there is at least one child living in household, and zero else. } \\
\text { (based on SHP variable hldtyp17) }\end{array}$ \\
\hline Interference work private life & $\begin{array}{c}\text { Interference of work with private life:. Dummy variable: is one if person reports that the work is } \\
\text { interfering with private activities/family obligations, zero else (based on the SHP variable } p 17 f 50 \text {, with } \\
10 \text { possible values }\{1, \ldots, 10\} \text {, where } 1=\text { not at all, } 10=\text { very strongly, and the dummy variable takes a } \\
\text { value of one if } p 17 f 50>5 \text { ) }\end{array}$ \\
\hline $\begin{array}{l}\text { Interference work private life } \\
\quad x \text { Manager }\end{array}$ & Interaction term of Interference work private life $x$ Manager \\
\hline
\end{tabular}

This table contains the definitions of the regression variables. The data source is the Swiss Household Panel provided by FORS. 
Table 2 reports descriptive statistics of our regression variables for the year 2017. We report the descriptive statistics as given by Table 2 separately for men and women, and we also include the difference between the values for men and for women and run two-sided means difference tests in order to check for the statistical significance between the sexes.

As to our explained variables satisfaction with life, the mean values for men and women are around 8, with no significant differences between the two groups. The mean job satisfaction is about 7.8, slightly lower for both, but women report a significantly higher job satisfaction then men, even though the difference is significant at the $10 \%$ level only. Satisfaction with the financial situation is about 7.2 for men and 7.4 for women, but the difference is not significant. In contrast to considering all job positions, we do find some differences in certain dimensions of the satisfaction levels when considering managers only. According to our descriptive statistics, women are financially happier than men, and this difference is statistically significant at the $10 \%$.

Looking at the descriptive statistics for the independent variables, the dummy variable Manager, which captures the share of persons in management positions, is about $19 \%$ significantly higher for men than for women, where the share of female managers amounts to about $8.5 \%$ only. These data reflect very well the unequal distribution of men and women across different professional hierarchies in the working population ${ }^{4}$. As to the variable Misqualification, about $20 \%$ of all men and women are over- or underqualified. In our sample, the average person is about 46 years, with no significant difference between men and women as well, and the share of Swiss among all is about $89 \%$. About $91 \%$ of men and about $87 \%$ of women reported to have good health, which is an overall quite high number. Another difference between the sexes refers to the university education: While about $47 \%$ of all men in our sample have enjoyed a university education, this share amounts to $36 \%$ for women, which is significantly lower. The household income differs also significantly between men and women, with significantly lower values for women. This observation has, among other factors, also to do with the fact that there are few female managers and women with university degrees, which both are expected to have an impact on the salary. Also, the work load might be different, and there are more women who work part-time. Note that we do not include the number of working hours into our model, given that this variable is correlated with the income as well as with the likelihood of being a manager.

About $78 \%$ of the men and $72 \%$ of the women in our sample are living together with a partner, and in about $81 \%$ of the households live children. Finally, $35 \%$ of the men and about $29 \%$ of the women in our sample witness interferences between the work and the private life. The difference is statistically significant, but we do not know the causes for these interferences. On the one hand, the higher stress likelihood for men might have to do with their higher job-related work load. On the other hand, women provide more household work instead, and the combination of both types of work could be a source for such interferences as well. The correlation coefficients can be found in the Appendix in Table A1. As expected, there exist some correlations between the variables, but multicollinearity does not seem to be a problem in our models.

\footnotetext{
4 According to the Federal Office of Statistics, $16.3 \%$ of all working women and $24.6 \%$ of all working men held management positions in Switzerland in 2016. the share of women in management positions in Switzerland amounted to about one third in 2016. See also https://www.bfs.admin.ch/bfs/de/home/statistiken/wirtschaftlichesoziale-situation-bevoelkerung/gleichstellung-frau-mann/erwerbstaetigkeit/beruflichestellung.assetdetail.2649633.html
} 
Table 2

Descriptive Statistics of the Regression Variables for The Year 2017

\begin{tabular}{|c|c|c|c|c|c|c|c|}
\hline Variable & & Men & & & Women & & \\
\hline $\begin{array}{l}\text { Dependent } \\
\text { variables }\end{array}$ & Mean & Median & Std.Dev & Mean & Median & Std.Dev & Difference \\
\hline Life satisfaction & 8.03 & 8 & 1.15 & 8.07 & 8 & 1.24 & -0.050 \\
\hline Job satisfaction & 7.80 & 8 & 1.32 & 7.87 & 8 & 1.44 & $-0.073^{*}$ \\
\hline $\begin{array}{l}\text { Financial } \\
\text { satisfaction } \\
\text { Independent } \\
\text { variables }\end{array}$ & 7.16 & 8 & 1.88 & 7.42 & 8 & 1.96 & -0.260 \\
\hline Manager & 0.18 & 0 & 0.39 & 0.08 & 0 & 0.28 & $0.102 * * *$ \\
\hline Misqualification & 0.19 & 0 & 0.39 & 0.19 & 0 & 0.39 & -0.008 \\
\hline Age & 46.49 & 48 & 11.02 & 46.19 & 48 & 11.09 & 0.301 \\
\hline Swiss & 0.89 & 1 & 0.31 & 0.89 & 1 & 0.30 & -0.002 \\
\hline Good health & 0.91 & 1 & 0.28 & 0.86 & 1 & 0.33 & $0.045^{* * * *}$ \\
\hline $\begin{array}{l}\text { University } \\
\text { education }\end{array}$ & 0.46 & 0 & 0.49 & 0.36 & 0 & 0.48 & $0.103 * * *$ \\
\hline $\begin{array}{l}\text { Household } \\
\text { income }\end{array}$ & 92.28 & $82^{\prime} 100$ & 53.86 & 51.39 & $47^{\prime} 900$ & 31.27 & $40^{\prime} 886^{* * *}$ \\
\hline $\begin{array}{l}\text { Living with } \\
\text { partner }\end{array}$ & 0.78 & 1 & 0.39 & 0.71 & 1 & 0.45 & $0.068 * * *$ \\
\hline $\begin{array}{l}\text { Children in } \\
\text { household }\end{array}$ & 0.80 & 1 & 0.38 & 0.80 & 1 & 0.39 & -0.001 \\
\hline $\begin{array}{l}\text { Interference } \\
\text { work private } \\
\text { life }\end{array}$ & 0.35 & 0 & 0.47 & 0.29 & 0 & 0.45 & $0.062 * * *$ \\
\hline $\begin{array}{l}\text { Manager x } \\
\text { Interf. work life }\end{array}$ & 0.09 & 0 & 0.29 & 0.03 & 0 & 0.17 & $0.063 * * *$ \\
\hline $\begin{array}{l}\text { Number of } \\
\text { observations }\end{array}$ & & 2’096 & & & 2’199 & & \\
\hline
\end{tabular}

\section{Analysis and Results}

Our analysis proceeds in two steps. First, we estimate our models with data for the year 2017. In the second step, we address the potential problem of reverse causality and investigate whether our underlying assumption of holding a management position having an effect on an individual's well-being is valid. For this purpose, we use the data for all the available years, namely from 2002 to 2017, but we only consider the individuals who had a change with respect to a management position, i.e. who moved in or out of a management position. Note that we also carried out robustness tests with the entire sample from 2002 to 2017, and the results are comparable to the ones for the latest year of 2017.

\section{Estimation Results for the Year 2017}

Table 3 reports the regression results for our main dependent variable satisfaction with life in general. As noted above, we estimate the models separately for men and women and sequentially include our sets of control variables, which is reflected in models (1) to (3), with model (3) being considered as our main results. As to our main variable of interest, the dummy variable Manager $_{i}$, we observe a positive and significant coefficient for both men and women, while the former effect seems stronger: A managerial position seems to have a positive impact on the life satisfaction in general for men, which confirms existing results, but also for women, which clearly contrasts with earlier findings by Brockmann, Koch, Diederich, and Edling (2018) and Trzcinski and Holst (2012) for Germany. Even though the influence is stronger for 
men, we report a positive and significant effect of being a manager on one's happiness for women as well. The reason for the contrasting results for women to the existing studies might at least partly have to do with the definition of a managerial position. Brockman et al. (2017) use the European version of the ISCO classification (ISCO-88) to define managerial status. Thus, managers are represented by corporate managers, directors/chief executives, production/operation managers, department managers, and general managers. Trzcincki and Holst (2012) define leaders and high-level managers on the basis of the respondents' own comments on their position in their occupation. These are functions with extensive managerial duties (e.g. managing director, manager, head of a large firm or concern) and other managerial functions or highly qualified duties (e.g., scientist, attorney, head of department). In our study, managers are defined as persons who hold a position in management or supervision, which is a rather broad definition and does not seem to differ so much from the other used definitions. Another potential reason for the difference might have to do with the time period of the data used. While Trzcincki and Holst (2012) use data for the time period from 1984 to 2006, the results of Brockmann et al. (2018) are based on data from the years 1984 to 2011. Our reported results use data from 2017, but we carried out robustness tests for the years 1999 to 2016, and the positive effect for women holds also for this time period. In contrast to both mentioned studies, our model does not include explanatory variables related to values and attitudes, because this information are not included in the Swiss Household Panel. We also exclude the number of hours worked in our reported results due to multicollinearty, but we included this information in our robustness tests. Finally, different preferences which are also reflected in the representation of women in management positions in different countries might be an additional explanation for the observed differences.

Unsurprisingly, being disqualified, either over- or underqualified, has an expected negative impact on the life satisfaction for men only. The household income positively affects satisfaction men and women, but the effect is very small and can be considered economically insignificant. A higher age makes men more unhappy, but not women. In contrast, being Swiss increases life satisfaction of women only. Unsurprisingly, enjoying good health has a highly significant positive effect on life satisfaction of men and women, while the impact seems even stronger for women. Having a university education does not affect the life satisfaction of the persons in our sample, but living together with a partner makes both men and women happier. Children in the household do not affect the general life satisfaction neither of the men nor of the women in our sample. As is known from other studies, children cause a lot of joy, but also have negative impacts on a person's happiness due to the additional work and costs children are causing (e.g., Pollmann-Schult, 2014), and the two effects seem to cancel each other out. Finally, let us turn to the variables which capture the interference between the work and the private life and allow us to draw some important conclusions about potential differences between men and women with respect to holding a management position and its likely impact on their subjective well-being. Looking at the coefficient of the variable Interference work

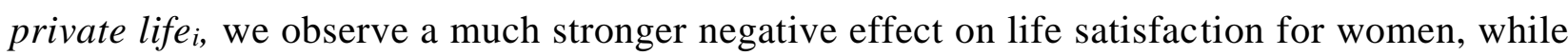
its impact is also significantly negative for men. According to our descriptive statistics in Table 2 , men are more likely than women to witness interferences between their job and the private life. 
Table 3

Results from Ordered Logit Regression for Satisfaction with Life in General

\begin{tabular}{|c|c|c|c|c|c|c|}
\hline \multirow{2}{*}{$\begin{array}{c}\text { Dependent variable: } \\
\text { Satisfaction with life in general }\end{array}$} & \multicolumn{3}{|c|}{ Men } & \multicolumn{3}{|c|}{ Women } \\
\hline & (1) & (2) & (3) & (1) & (2) & (3) \\
\hline \multirow[t]{2}{*}{ Manager } & $0.319 * * *$ & $0.155^{* *}$ & $0.332 * * *$ & $0.340 * *$ & $0.293 * *$ & $0.265^{*}$ \\
\hline & $(0.105)$ & $(0.074)$ & $(0.100)$ & (0.146) & $(0.121)$ & $(0.160)$ \\
\hline \multirow{2}{*}{ Misqualification } & $-0.403 * * *$ & $-0.213 * * *$ & $-0.195 * * *$ & $-0.248 * *$ & -0.1312 & -0.110 \\
\hline & $(0.070)$ & $(0.069)$ & $(0.070)$ & $(0.108)$ & $(0.083)$ & $(0.093)$ \\
\hline \multirow[t]{2}{*}{ Household income } & & 0.000 & $0.000^{* * *}$ & & 0.000 & $0.000 * *$ \\
\hline & & $(0.000)$ & $(0.000)$ & & $(0.022)$ & $(0.000)$ \\
\hline \multirow{2}{*}{ Age } & & $-0.043 * *$ & $-0.072 * * *$ & & -0.027 & -0.410 \\
\hline & & $(0.020)$ & $(0.021)$ & & $(0.023)$ & $(0.025)$ \\
\hline \multirow[t]{2}{*}{ Age squared } & & $0.001 * *$ & $0.001 * * *$ & & 0.000 & $0.001 * *$ \\
\hline & & (0.000) & (0.000) & & $(0.000)$ & $(0.000)$ \\
\hline \multirow[t]{2}{*}{ Swiss } & & $0.143^{*}$ & 0.124 & & $0.304 * * *$ & $0.232 * *$ \\
\hline & & $(0.084)$ & $(0.085)$ & & $(0.107)$ & $(0.115)$ \\
\hline \multirow[t]{2}{*}{ Good health } & & $0.843 * * *$ & $0.836^{* * *}$ & & $1.255^{* * * *}$ & $1.273 * * *$ \\
\hline & & $(0.140)$ & $(0.142)$ & & $(0.130)$ & $(0.135)$ \\
\hline University education & & $\begin{array}{c}0.038 \\
(0.052)\end{array}$ & $\begin{array}{c}0.040 \\
(0.055)\end{array}$ & & $\begin{array}{c}0.013 \\
(0.072)\end{array}$ & $\begin{array}{c}0.020 \\
(0.077)\end{array}$ \\
\hline \multirow[t]{2}{*}{ Living with partner } & & & $0.742 * * *$ & & & $0.586 * * *$ \\
\hline & & & $(0.208)$ & & & $(0.127)$ \\
\hline Children in household & & & $\begin{array}{l}-0.213 \\
(0.207)\end{array}$ & & & $\begin{array}{l}-0.149 \\
(0.141)\end{array}$ \\
\hline Interference work private life & & & $\begin{array}{c}-0.257 * * * \\
(0.067)\end{array}$ & & & $\begin{array}{c}-0.645^{* * * *} \\
(0.091) \\
\end{array}$ \\
\hline $\begin{array}{l}\text { Manager } x \text { Interference work } \\
\text { private life }\end{array}$ & & & $\begin{array}{l}-0.268^{*} \\
(0.138)\end{array}$ & & & $\begin{array}{c}0.278 \\
(0.260)\end{array}$ \\
\hline $\mathrm{LR} \mathrm{chi}^{2}$ & 25.32 & 159.18 & 253.14 & 20.70 & 195.11 & 307.98 \\
\hline Observations & & $2 ’ 096$ & & & 199 & \\
\hline
\end{tabular}

This table reports results for the year 2017 from heteroskedastic ordinal regressions of the effects of work-related, person-specific and integration-specific factors on the satisfaction with life in general. Reported are Odds Ratios. The definition of the variables are given in Table 1. Robust standard errors in brackets. Coefficients that are significantly different from zero at the $1 \%, 5 \%$, and $10 \%$ level are marked with $* * *, * *$, and * respectively.

Notwithstanding, this factor, which is much related to stress, affects women more than men. The inclusion of the interaction between this interference variable and the dummy variable Manager reveals very interesting differences between men and women with respect to their different preferences or at least choice of the respective jobs. The coefficient of this interaction term is insignificant for women, but highly significant and negative for men. In other words, men holding a management position and having at the same time interferences between the work and the private life witness a serious negative effect on their subjective well-being. Women in similar situations, also holding a management position and having at the same time interferences between the job and the private life do not suffer from such negative effects on their happiness. Accordingly, women seem to be more immune to such stress and do not witness a negative impact on their satisfaction with life in general.

Our second measure of subjective well-being refers to the satisfaction with the job. We carried out the same analyses and consider the effects of the different factors again separately for men and women, and the results can be found in Table 4 . Note that this satisfaction dimension uniquely refers to the job satisfaction. Being a manager increases the job satisfaction of both men and women, with stronger effects for men. Being disqualified negatively affects both men and women, and the corresponding effects are quite large, with even stronger effects for men. Note that disqualification did not negatively affect the satisfaction with life in general for women. A higher age affects the job satisfaction of men only, and the nationality as well as having a university education does not seem to matter for both men and women. Unsurprisingly, healthy people enjoy a higher job satisfaction, and living with a partner affects only the job satisfaction of women, and 
this in a positive way, but having children in the household implies a negative effect on the job satisfaction of women, while men do not seem to care. In contrast, interference between work and private life negatively impacts both men and women. As to the coefficient of the interaction term, which is telling is whether this interference is more severe for managers, we do not find a negative impact for men like for our first measure satisfaction with life in general. But we report a positive coefficient for women, which confirms the finding that women in management positions seem to be more immune to stress in comparison to men, that is, interference between private life and work also affect their job satisfaction, but female managers suffer less in comparison both to women without management positions.

The results for our third measure of subjective well-being can be found in

Table 5, where we consider the satisfaction with the financial situation. Focusing on the full model in columns (3), we identify again some differences between men and women. In particular, holding a management position does not affect the satisfaction with the financial situation of women and men. Being disqualified, however, has a negative impact on the financial situation of men. Again, age negatively affects men only, but being Swiss has a positive impact both on the satisfaction with the financial situation of both men and women, so does enjoying good health and having a university degree. Living with a partner positively and having children negatively affects the situation of women only, and interference is negative for both women and men. The positive and significant coefficient of the interaction term for women only confirms the higher stress resistance of female managers to work-life interferences. These results are all in line with those for the job satisfaction.

Table 4

Results from Ordered Logit Regression for Satisfaction with the Job

\begin{tabular}{|c|c|c|c|c|c|c|}
\hline \multirow{2}{*}{$\begin{array}{l}\text { Dependent variable: } \\
\text { Satisfaction with job }\end{array}$} & \multicolumn{3}{|c|}{ Men } & \multicolumn{3}{|c|}{ Women } \\
\hline & (1) & (2) & (3) & (1) & (2) & (3) \\
\hline Manager & $\begin{array}{c}0.652 * * * \\
(0.105)\end{array}$ & $\begin{array}{c}0.637 * * * \\
(0.111)\end{array}$ & $\begin{array}{c}0.785^{* * * *} \\
(0.150)\end{array}$ & $\begin{array}{c}0.999 * * * \\
(0.145)\end{array}$ & $\begin{array}{c}0.908^{* * *} * \\
(0.136)\end{array}$ & $\begin{array}{c}0.719 * * * \\
(0.168)\end{array}$ \\
\hline Misqualification & $\begin{array}{c}-0.970 * * * \\
(0.119)\end{array}$ & $\begin{array}{c}-0.947 * * * \\
(0.119)\end{array}$ & $\begin{array}{c}-0.946^{* * * *} \\
(0.120)\end{array}$ & $\begin{array}{c}-0.756 * * * \\
(0.115)\end{array}$ & $\begin{array}{c}-0.632 * * * \\
(0.105)\end{array}$ & $\begin{array}{c}-0.632 * * * \\
(0.107)\end{array}$ \\
\hline Household income & & $\begin{array}{c}0.000 \\
(0.000)\end{array}$ & $\begin{array}{c}0.000 \\
(0.000)\end{array}$ & & $\begin{array}{l}0.000^{*} \\
(0.000)\end{array}$ & $\begin{array}{c}0.000 \\
(0.000)\end{array}$ \\
\hline Age & & $\begin{array}{c}-0.096^{* * * *} \\
(0.315)\end{array}$ & $\begin{array}{c}-0.108 * * * \\
(0.032)\end{array}$ & & $\begin{array}{c}-0.049 * * \\
(0.244)\end{array}$ & $\begin{array}{l}-0.040 \\
(0.025)\end{array}$ \\
\hline Age squared & & $\begin{array}{c}0.001 * * * \\
(0.000)\end{array}$ & $\begin{array}{c}0.001 * * * \\
(0.000)\end{array}$ & & $\begin{array}{c}0.001 * * * \\
(0.000)\end{array}$ & $\begin{array}{c}0.001 * * \\
(0.000)\end{array}$ \\
\hline Swiss & & $\begin{array}{c}0.137 \\
(0.137)\end{array}$ & $\begin{array}{c}0.109 \\
(0.137)\end{array}$ & & $\begin{array}{l}0.266^{* *} \\
(0.115)\end{array}$ & $\begin{array}{c}0.183 \\
(0.116)\end{array}$ \\
\hline Good health & & $\begin{array}{c}0.428 * * * \\
(0.150)\end{array}$ & $\begin{array}{c}0.409 * * * \\
(0.150)\end{array}$ & & $\begin{array}{l}0.471^{* * * *} \\
(0.119)\end{array}$ & $\begin{array}{c}0.431 * * * \\
(0.119)\end{array}$ \\
\hline University education & & $\begin{array}{c}0.016 \\
(0.086)\end{array}$ & $\begin{array}{c}0.047 \\
(0.086)\end{array}$ & & $\begin{array}{l}-0.078 \\
(0.077)\end{array}$ & $\begin{array}{c}-0.044 \\
0.078\end{array}$ \\
\hline Living with partner & & & $\begin{array}{c}0.070 \\
(0.288)\end{array}$ & & & $\begin{array}{c}0.336^{* * * *} \\
(0.124)\end{array}$ \\
\hline Children in household & & & $\begin{array}{c}0.409 \\
(0.301)\end{array}$ & & & $\begin{array}{c}-0.307 * * \\
(0.143)\end{array}$ \\
\hline Interference work private & & & $-0.580 * * *$ & & & $-0.565^{* * *}$ \\
\hline life & & & $(0.100)$ & & & $(0.088)$ \\
\hline $\begin{array}{l}\text { Manager } x \text { Interference } \\
\text { work private life }\end{array}$ & & & $\begin{array}{l}-0.018 \\
(0.212)\end{array}$ & & & $\begin{array}{l}0.629 * * \\
(0.257)\end{array}$ \\
\hline $\begin{array}{l}\text { LR chi }{ }^{2} \\
\text { Observations }\end{array}$ & 173.26 & $\begin{array}{l}168.81 \\
2 ’ 096\end{array}$ & 230.48 & 118.87 & $\begin{array}{l}201.82 \\
2 ’ 199\end{array}$ & 258.58 \\
\hline
\end{tabular}

This table reports results for the year 2017 from heteroskedastic ordinal regressions of the effects of work-related, person-specific and integration-specific factors on the satisfaction with the job. The definition of the variables are given in Table 1. Robust standard errors in brackets. Coefficients that are significantly different from zero at the $1 \%, 5 \%$, and $10 \%$ level are marked with $* * *, * *$, and $*$ respectively. 
Table 5

Results from Ordered Logit Regression for Satisfaction with the Financial Situation

\begin{tabular}{|c|c|c|c|c|c|c|}
\hline $\begin{array}{l}\text { Dependent variable: } \\
\text { Satisfaction with financial } \\
\text { situation }\end{array}$ & (1) & $\begin{array}{l}\text { Men } \\
(2)\end{array}$ & (3) & (1) & $\begin{array}{l}\text { Women } \\
\text { (2) }\end{array}$ & (3) \\
\hline Manager & $\begin{array}{c}0.292 * * * \\
(0.150)\end{array}$ & $\begin{array}{c}-0.195 * * \\
(0.088)\end{array}$ & $\begin{array}{l}-0.095 \\
(0.119)\end{array}$ & $\begin{array}{c}0.126 \\
(0.108)\end{array}$ & $\begin{array}{l}-0.071 \\
(0.130)\end{array}$ & $\begin{array}{l}-0.302 \\
(0.184)\end{array}$ \\
\hline Misqualification & $\begin{array}{c}-0.568 * * * \\
(0.058)\end{array}$ & $\begin{array}{c}-0.329 * * * \\
(0.085)\end{array}$ & $\begin{array}{c}-0.315^{* * * *} \\
(0.085)\end{array}$ & $\begin{array}{c}-0.261 * * * \\
(0.098)\end{array}$ & $\begin{array}{l}-0.115 \\
(0.077)\end{array}$ & $\begin{array}{l}-0.081 \\
(0.086)\end{array}$ \\
\hline Household income & & $\begin{array}{c}0.000 * * * \\
(0.000)\end{array}$ & $\begin{array}{c}0.000 * * * \\
(0.000)\end{array}$ & & $\begin{array}{c}0.000 * * * \\
(0.000)\end{array}$ & $\begin{array}{c}0.000^{* * *} \\
(0.000)\end{array}$ \\
\hline Age & & $\begin{array}{c}-0.071 * * * \\
(0.025)\end{array}$ & $\begin{array}{c}-0.070 * * * * \\
(0.025)\end{array}$ & & $\begin{array}{l}-0.011 \\
(0.021)\end{array}$ & $\begin{array}{l}-0.015 \\
(0.025)\end{array}$ \\
\hline Age squared & & $\begin{array}{c}0.001 * * * \\
(0.000)\end{array}$ & $\begin{array}{c}0.001 * * * \\
(0.000)\end{array}$ & & $\begin{array}{c}0.000 \\
(0.000)\end{array}$ & $\begin{array}{c}0.000 \\
(0.000)\end{array}$ \\
\hline Swiss & & $\begin{array}{c}0.250 * * \\
(0.103)\end{array}$ & $\begin{array}{c}0.245 * * \\
(0.103)\end{array}$ & & $\begin{array}{c}0.367 * * * \\
(0.099)\end{array}$ & $\begin{array}{c}0.353^{*} * * \\
(0.112)\end{array}$ \\
\hline Good health & & $\begin{array}{c}0.492 * * * \\
(0.140)\end{array}$ & $\begin{array}{c}0.472 * * * \\
(0.140)\end{array}$ & & $\begin{array}{c}0.501 * * * \\
(0.106)\end{array}$ & $\begin{array}{c}1.541 * * * \\
(0.116)\end{array}$ \\
\hline University education & & $\begin{array}{l}1.177 * * \\
(0.069)\end{array}$ & $\begin{array}{c}0.191 * * * \\
(0.069)\end{array}$ & & $\begin{array}{l}0.113^{*} \\
(0.067)\end{array}$ & $\begin{array}{l}0.130^{*} \\
(0.077)\end{array}$ \\
\hline Living with partner & & & $\begin{array}{c}0.343 \\
(0.229)\end{array}$ & & & $\begin{array}{c}0.953 * * * \\
(0.130)\end{array}$ \\
\hline Children in household & & & $\begin{array}{l}-0.230 \\
(0.237)\end{array}$ & & & $\begin{array}{c}-0.478 * * * \\
(0.138)\end{array}$ \\
\hline Interference work private & & & $-0.288 * * *$ & & & $-0.442 * * *$ \\
\hline life & & & $(0.077)$ & & & $(0.081)$ \\
\hline $\begin{array}{l}\text { Manager x Interference } \\
\text { work private life }\end{array}$ & & & $\begin{array}{l}-0.960 \\
(0.166)\end{array}$ & & & $\begin{array}{l}0.523^{*} \\
(0.302)\end{array}$ \\
\hline LR chi $^{2}$ & 47.15 & 311.62 & & 27.93 & 244.48 & 346.92 \\
\hline Observations & & 2’096 & 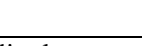 & & 2’199 & \\
\hline
\end{tabular}

In addition to the aforementioned robustness tests, we additionally checked whether women who are also mothers behave differently to those who do not have own children. Even though we control for the fact of having children in the household, we estimated the models separately for mothers, and found that the results are robust.

\section{Reverse Causality Problem: Consideration of Persons with Change in Their Job Position with Respect to Management Duties}

Our results outlined above provide empirical evidence for existing differences between men and women in terms of the impact of holding a management position on their subjective well being. While being a manager increases the subjective well-being of both men and to a lesser extent also women, existing interferences between work and the private life while being a manager negatively affect the satisfaction of life of men only, and women in management positions seem to suffer less from these interferences. Given that we control for a range of other commonly acknowledged factors that are expected to affect an individual's well-being, it is less likely that this effect is driven by some other unobservable factors, which are not included in our model.

Notwithstanding, our claim is based on the underlying assumption that holding a management position causes happiness. However, one could argue that managers are per se happier than persons without management jobs, because they have, for instance, a more positive attitude towards life in general, and due to this state of mind they are more likely to choose or 
being chosen for a management position. In contrast to other studies (e.g., Trzcinski \& Holst, 2012; Brockman et al., 2017), we try to address this potential reverse causality problem in the following way: We use the sample for all available years from 2002 to 2017, but we consider only those individuals who had a change in their job position with respect to management duties over the time period considered, and no changes in the other control variables expect changes in age, working time and income. We then look at how their satisfaction level has changed depending on the change in their job duties, i.e. depending on whether they moved in or out of a management job. If moving from a non-management position to a management position increased the individuals' subjective well-being, we would take this as evidence to support the assumed causality of holding a management position leading having an impact on the subjective well-being.

Table 6 gives an overview of the sample. In total, there are 44647 individuals in our sample over the years 2002 to 2017, where 8436 persons hold a manager position and 49653 do not hold a manager position, 3938 individuals have changed their job status: 1872 persons with a management position changed to a non-management position, and 2066 without a management position moved into a management position over the time period considered. Keeping only those observations with no changes in the control variables in our sample, we are left with 1467 persons that moved from a management position to a non-management position, and 1652 persons without management position who took over a management position. Out of them, 244 of the managers who became non-managers and 270 non-managers who became managers also have a change in their satisfaction of life.

Table 6

Number of Individuals in the Restricted Sample from 2002 To 2017

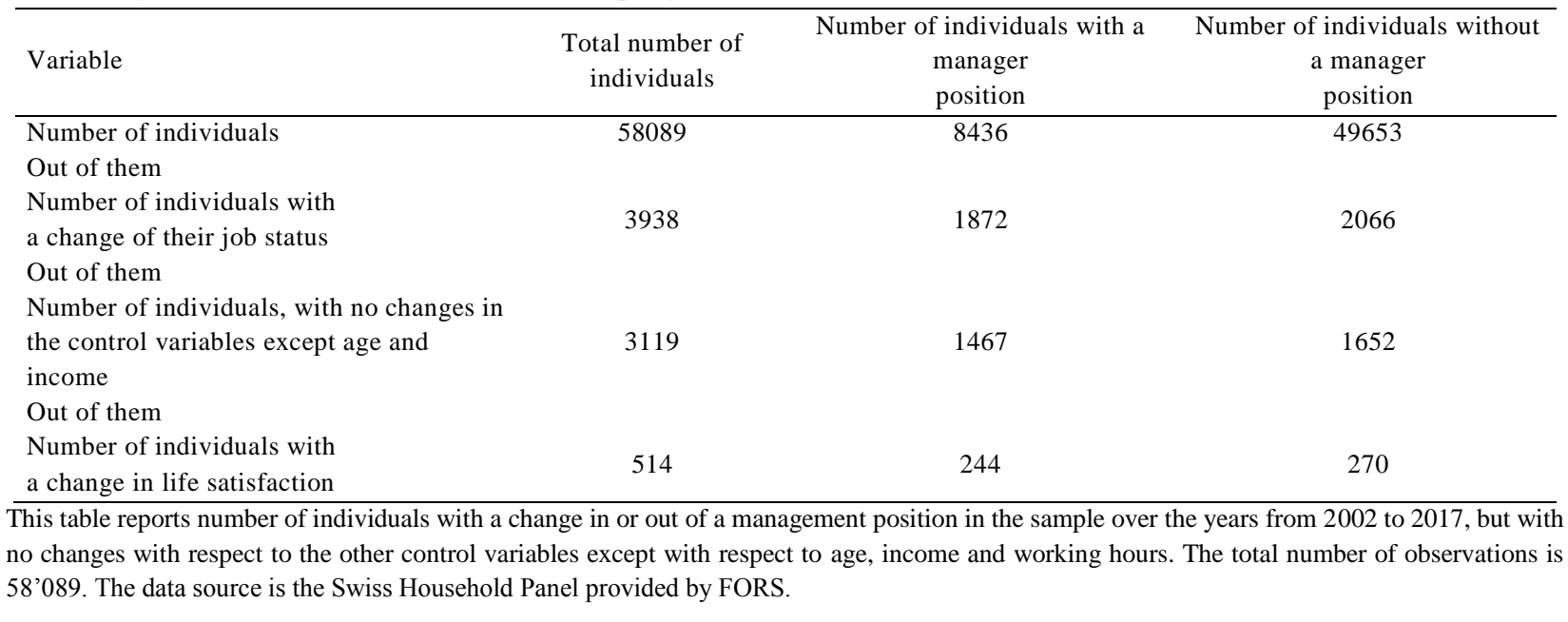

The descriptive statistics for those 514 observations with a change in life satisfaction (and a change in the job status and no changes in the control variables except age and income) are given in Table 8 . Note that the descriptive statistics of the control variables are rather similar to the ones for our main sample for the year 2017 as given in Table 2.

To address this potential reverse causality issue and the particular question whether our underlying assumption of holding a management position is having an impact on the subjective well-being is valid, we divide each of the two groups, i.e. managers who become not managers, in those who become happier and those who become less happy. 
Table 7

Descriptive Statistics of the Restricted Sample for the Years 2002 to 2015

\begin{tabular}{|c|c|c|c|}
\hline Variable & Mean & Median & Std.Dev \\
\hline \multicolumn{4}{|l|}{ Dependent variables } \\
\hline Life satisfaction & 8.11 & 8.00 & 1.19 \\
\hline \multicolumn{4}{|l|}{ Independent variables } \\
\hline Manager & 0.53 & 1.00 & 0.50 \\
\hline Misqualification & 0.11 & 0.00 & 0.32 \\
\hline Age & 50.48 & 50.00 & 10.62 \\
\hline Swiss & 0.92 & 1.00 & 0.28 \\
\hline Good health & 0.95 & 1.00 & 0.22 \\
\hline University education & 0.39 & 0.00 & 0.49 \\
\hline Household income & $69^{\prime} 015$ & $60 ' 000$ & $56 ' 146$ \\
\hline Living with partner & 0.78 & 1.00 & 0.42 \\
\hline Children in household & 0.83 & 1.00 & 0.38 \\
\hline Number of observations & & 514 & \\
\hline
\end{tabular}

We then calculate the odds ratio to quantitatively describe the association between the happiness of the two groups according to the following formula (4):

$$
\text { Odds ratio }=\text { odds rato }=\frac{a / c}{b / d}=\frac{a \times d}{b \times d}
$$

Where as

$a$ : not managers becoming managers and getting happier

$b$ : managers becoming not managers and getting happier

$c$ : not managers becoming managers and getting less happy

$d$ : manager becoming not manager and getting less happy

An odds ratio of 1 indicates that there is no difference between the happiness of the two groups. An odds ratio greater than 1 indicates that the chance to be happy in the group of the individuals moving form a job without management duties into a job with management duties is more likely to occur than in the group of individuals with a management job moving to a non-management position. Correspondingly, an odds ratio of less than 1 indicates that the chance that non-managers who became managers are happier is less likely to occur than the chance that managers who become non-managers are happier. An odds ratio greater than 1, therefore, would support our assumption that a management position causes happiness. If the reverse causality were true, we would expect an odds ratio less than 1 .

The corresponding results can be found in Table 9. Overall, from the 270 individuals in our sample that moved from being a non-manager to becoming a manager, 132 persons became happier and 138 persons became less happy, while from the 244 managers who moved into a nonmanager position 111 became happier and 133 less happy. The generated odds ratio is about 1.15. The chance to become happier is 1.15 times higher in the group of non-managers who became managers than in the group with managers who became non-managers. We use this result to support our assumption that having a management position makes people happier. If managers were per se happier than non-managers, we would expect an odds ratio of 1 and, therefore, would not find any differences between the two groups. Accordingly, we expect the underlying assumption of holding 
a management position having an effect of a person's subjective well-being being valid, and we are confident that our results do not suffer from a reverse causality issue.

Table 9

Individuals with Change in Job Status over the Years 2002 to 2017: Odds Ratio

\begin{tabular}{lcc} 
& Non-managers who became managers & Managers who became non-manager \\
\hline Became more satisfied & 132 & 111 \\
Became less satisfied & 138 & 133 \\
Total number & 270 & 244 \\
Odds ratio & & 243 \\
\hline This table reports the number of individuals with a change in their job status with respect to holding a management position and with a change in \\
their level of life satisfaction in the restricted sample over the years from 2002 to 2017 with a change in life satisfaction and a change in the job \\
status and no changes in the control variables except age, income and working hours) for the years 2002 to 2017 and and the corresponding odds \\
ratio. The number of observations is 514. The data source is the Swiss Household Panel provided by FORS.
\end{tabular}

\section{Conclusions}

Being happy is the goal of most if not all individuals (e.g., Diener et al., 1995; Diener, 2000; Veenhoven, 2010). At the same time, the average person among the working population spends a significant share of his or her time at work, the professional environment and the respective working conditions are expected to affect a person's happiness significantly. Among all jobs, management positions represent tasks which are particularly interesting. For once, management jobs are generally associated with an above average amount of responsibilities, interesting work duties with decision power, financial benefits and social prestige. At the same time, such positions are expected to require long working hours, a high personal involvement and possibly also stress, and there is less time left to spend with families, friends and for leisure activities. Accordingly, the outcome of holding such a position on an individual's well-being is a priori unclear, given that there are positive as well as negative factors which are all expected to affect a person's happiness. In addition, we observe a rather distinguished inequality between men and women in management position in Switzerland, where the share of women with management duties amounted to about $36 \%$ in $2017 .^{5}$ The question arises whether and how these issues are related to each other, and whether the differences with respect to the subjective well-being of women and men are one of several explanatory factors to explain this inequality.

The purpose of our study was to investigate the impact of holding a management position on satisfaction with life in general, job satisfaction as well as satisfaction with the financial situation and to explore potential differences between men and women. Our main results from the regression analyses, which analyze the determinants of individual well-being or satisfaction, provide evidence for the fact that holding a management position has a strong and positive effect on the life satisfaction of men, but a weaker but still a positive effect on the life satisfaction of women, at least in our model specification with all the control variables. Existing interferences between the work and private life negatively affects the well-being of both men and women. But when one considers managers only, such interferences between work and private life only affect the life satisfaction of men in management positions in a negative way, while women in management positions seem to be more stress resistant in this respect. This result is interesting because it points out to the large potential of women, who are still largely underrepresented in management jobs. Note that we control for a large set of person-specific, work-specific as well as integration-specific factors which

\footnotetext{
${ }^{5}$ See also https://www.bfs.admin.ch/bfs/de/home/statistiken/kataloge-datenbanken/grafiken.assetdetail.2680648.html.
} 
all are expected to impact subjective well-being. Also, we show that our results are not driven by a potential endogeneity problem due to a reverse causality effect.

Our paper is the first empirical study that investigates the impact of management positions on life-, job and financial satisfaction and whether there exist any differences between men and women for Switzerland. More research is necessary to further explore these issues in order to better understand the underlying mechanisms. For instance, it might be interesting for Switzerland as well to integrate the impacts of biological constraints related to women's fertility when studying both subjective life satisfaction as well as career choices of women and men, as was studied by Brockmann et al. (2017) for Germany. Also, it could be fruitful to differentiate between women's preferences, i.e. do women want to pursue a career with management duties, versus the institutional availabilities and constraints. Furthermore, repeating the analyses in a few years might show some significant differences, given that Switzerland is currently discussing on a political level whether target values of women on boards and in management positions of publicly listed should be introduced. Finally, future work should focus on how organizations best adjust the institutional settings, the incentive schemes to match the preferences of their employees, and in particular to offer the relevant jobs with the necessary organizational and institutional flexibilities to women in management positions.

\section{References}

Brockmann, H., Koch, A. M., Diederich, A., \& Edling, C. (2018). Why managerial women are less happy than managerial men. Journal of Happiness Studies, 19(3), 755-779.

Bucchianeri, G. W. (2011). The American dream or the American delusion? the private and external benefits of homeownership for women. Retrieved from SSRN: http://ssrn.com/abstract=1877163 or http://dx.doi.org/10.2139/ssrn.1877163.

Dawson, J., Kersley, R., \& Natella, S. (2016). The CS gender 3000: The reward for change. Zurich, Switzerland: Credit Suisse Research Institute.

Diener, E., Suh, E. M., Smith, H., \& Shao, L. (1995). National differences in reported subjective well-being: Why do they occur? Social Indicators Research, 34(1), 7-32.

Diener, E. (2000). Subjective well-being: The science of happiness and a proposal for a national index. American Psychologist, 55(1), 34-43.

Easterlin, R. A. (2001). Income and happiness: Towards a unified theory. The Economic Journal, 111(473), 465-484.

Frey, B. S., \& Stutzer, A. (2002). What can economists learn from happiness research? Journal of Economic Literature, 40(2), 402-435.

Frey, B. S., \& Stutzer, A. (2005). Happiness research: State and prospects. Review of Social Economics, 62(2), $207-228$.

Frey, B. S., \& Stutzer, A. (2010). Recent advances in the economics of individual subjective well-being. Social Research: An International Quarterly, 77(2), 679-714.

Gazareth, P., Iglesias K., Crettaz E., \& Suter, C. (2018). Between social structure inertia and changing biographies: trajectories of material deprivation in Switzerland. In R. Tillmann, M. Voorposte, \& P. Farago (Eds), Social dynamics in Swiss society. Life course research and social policies (pp. 113-128). Cham: Springer.

Lyubomirsky, S., King, L., \& Diener, E. (2005). The benefits of frequent positive affect: Does happiness lead to success? Psychological Bulletin, 131(6), 803-855.

Pollmann-Schult, M. (2014). Parenthood and life satisfaction: Why don't children make people happy? Journal of Marriage and Family, 76(2), 319-336.

Treas, J., van der Lippe, T., \& Tai, T. O. C. (2011). The happy homemaker? Married women's well-being in cross-national perspective. Social forces, 90(1), 111-132.

Trzcinski, E., \& Holst, E. (2012). Gender differences in subjective well-being in and out of management positions. Social Indicators Research, 107(3), 449-463.

Veenhoven, R. (2010). How universal is happiness? In E. Diener, J. F. Helliwell, \& D. Kahneman (Eds.), International differences in well-being (pp. 328-350). New York: Oxford University Press. 
Veenhoven, R. (2013). Notions of the good life. In S. A. David, I. Boniwell, \& A. C. Ayers (Eds.), The Oxford handbook of happiness (pp. 161-173). Oxford: Oxford University Press.

Yatchew, A., \& Griliches, Z. (1985). Specification error in probit models. The Review of Economics and Statistics, 134-139. 


\section{Appendix}

Table A1

Correlation Matrix

\begin{tabular}{|c|c|c|c|c|c|c|c|c|c|c|c|c|c|c|c|}
\hline & $\begin{array}{l}\text { Satis. in } \\
\text { general }\end{array}$ & $\begin{array}{c}\text { Job } \\
\text { satsif. }\end{array}$ & $\begin{array}{l}\text { Financial } \\
\text { satsif. }\end{array}$ & Manager & Misqual. & $\begin{array}{c}\mathrm{Hh} \\
\text { income }\end{array}$ & Age & Age sq. & Swiss & $\begin{array}{l}\text { Good } \\
\text { health }\end{array}$ & $\begin{array}{l}\text { Univ. } \\
\text { educ }\end{array}$ & $\begin{array}{l}\text { Liv. w. } \\
\text { partner }\end{array}$ & $\begin{array}{l}\text { Children } \\
\text { in hh }\end{array}$ & $\begin{array}{l}\text { Interf. } \\
\text { work } \\
\text { life }\end{array}$ & $\begin{array}{c}\text { Manager x } \\
\text { Interf. } \\
\text { work life }\end{array}$ \\
\hline Satis. in general & 1.00 & & & & & & & & & & & & & & \\
\hline Job satsif. & 0.40 & 1.00 & & & & & & & & & & & & & \\
\hline Financial satsif. & 0.42 & 0.29 & 1.00 & & & & & & & & & & & & \\
\hline Manager & 0.05 & 0.12 & 0.02 & 1.00 & & & & & & & & & & & \\
\hline Misqual. & -0.09 & -0.20 & -0.10 & -0.05 & 1.00 & & & & & & & & & & \\
\hline Hh income & 0.05 & 0.03 & 0.21 & 0.30 & -0.10 & 1.00 & & & & & & & & & \\
\hline Age & 0.02 & 0.10 & 0.15 & 0.10 & -0.02 & 0.12 & 1.00 & & & & & & & & \\
\hline Age sq. & 0.02 & 0.11 & 0.15 & 0.09 & -0.02 & 0.11 & 0.99 & 1.00 & & & & & & & \\
\hline Swiss & 0.04 & 0.06 & 0.07 & 0.01 & -0.04 & 0.02 & 0.02 & 0.03 & 1.00 & & & & & & \\
\hline Good health & 0.26 & 0.09 & 0.13 & 0.03 & -0.05 & 0.08 & -0.08 & -0.08 & -0.01 & 1.00 & & & & & \\
\hline Univ. educ & 0.01 & -0.02 & 0.11 & 0.12 & 0.01 & 0.32 & -0.07 & -0.08 & -0.04 & 0.05 & 1.00 & & & & \\
\hline Liv. w. partner & 0.16 & 0.06 & 0.11 & 0.00 & -0.03 & 0.03 & 0.04 & 0.03 & 0.00 & 0.04 & 0.01 & 1.00 & & & \\
\hline Children in hh & 0.12 & 0.05 & 0.07 & 0.01 & -0.03 & 0.01 & 0.09 & 0.07 & -0.01 & 0.01 & 0.01 & 0.84 & 1.00 & & \\
\hline Interf. work life & -0.14 & -0.15 & -0.07 & 0.12 & 0.01 & 0.15 & -0.04 & -0.05 & -0.06 & -0.03 & 0.12 & -0.01 & -0.01 & 1.00 & \\
\hline Manager x Interf. work life & -0.01 & 0.05 & 0.00 & 0.66 & -0.03 & 0.24 & 0.03 & 0.02 & 0.00 & 0.02 & 0.09 & 0.02 & 0.01 & 0.38 & 1.00 \\
\hline
\end{tabular}

This table reports correlation coefficients of the regression variables for the year 2017. The number of observations is 4'295. The data source is the Swiss Household Panel provided by FORS. 